This item was submitted to Loughborough's Research Repository by the author.

Items in Figshare are protected by copyright, with all rights reserved, unless otherwise indicated.

\title{
The future of design for sustainable behaviour revisited
}

PLEASE CITE THE PUBLISHED VERSION

VERSION

AM (Accepted Manuscript)

\section{PUBLISHER STATEMENT}

This work is made available according to the conditions of the Creative Commons Attribution-NonCommercialNoDerivatives 4.0 International (CC BY-NC-ND 4.0) licence. Full details of this licence are available at: https://creativecommons.org/licenses/by-nc-nd/4.0/

\section{LICENCE}

CC BY-NC-ND 4.0

\section{REPOSITORY RECORD}

Boks, Casper, Debra Lilley, and Ida Nilstad Pettersen. 2019. "The Future of Design for Sustainable Behaviour Revisited". figshare. https://hdl.handle.net/2134/20739. 


\title{
The future of design for sustainable behaviour, revisited
}

\author{
Casper Boks ${ }^{1}$, Debra Lilley ${ }^{2}$, Ida Nilstad Pettersen ${ }^{1}$ \\ ${ }^{1}$ Department of Product Design, Norwegian University of Science and Technology, Norway \\ ${ }^{2}$ Loughborough Design School, Loughborough University, United Kingdom
}

\begin{abstract}
At the 2009 Ecodesign conference the results of a survey on the future of Design for Sustainable Behavior (DfSB) was presented. In this paper, the survey is revisited, and responses from both surveys are compared and discussed. The contribution of theoretical fields, research priorities, integration in business, and the location and position of DfSB are discussed. The current discourse on behavior versus practice oriented research is addressed, and the paper concludes with thoughts on how DfSB may further mature as research area.
\end{abstract}

Keywords:

Design research, sustainable behaviour, sustainable practices

\section{INTRODUCTION}

In recent years, increasing attention has been directed towards the environmental impacts caused during the use phase of products and the significance of the way people behave and interact with products has been acknowledged. This interest has resulted in a research field investigating how it may be possible to influence people's everyday activities through design, to reduce their environmental burden. This field is often referred to as Design for Sustainable Behaviour (DfSB), although the correctness of this term is debated by, for example, practice theorists. A growing range of case studies have been published (an overview of 28 case studies is presented in Daae and Boks [1], and ethical aspects of designers and industry influencing user behaviour have also been addressed [2,3]. Within Northern Europe, researchers in this field have found each other in a research network that meets annually, and several dedicated special issues on the topic have been published in academic journals (see Figure 1).

In the proceedings of the Ecodesign2009 conference, the results of a survey on the future of design for sustainable behaviour were presented [4]. The survey was designed to map the opinions of researchers most active in this emerging field. The study addressed expectations on which academic fields were to contribute significantly to the further development of the field, which topics were most likely to receive external research funding, as well as priorities that should and would be given to theoretical, applied and design-oriented, and management and organisation-oriented research. Another part of the survey addressed questions related to which design strategies would turn out to be most relevant for various (household) practices and behaviours in general, including an assessment of the importance of various factors on the adoption and appropriate use of DfSB strategies. Based on this, a new adapted version of the survey was sent out to scholars within this field, to assess how the field has developed since then, to address future developments, and as such document research progress within DfSB research, to potentially fuel discussion on a common future research agenda.

The paper is structured as follows. First, the development of the DfSB field is briefly sketched. Then, the results of the 2015 survey are presented, and where appropriate compared to the results of the 2009 survey, leading to a discussion of to what extent expectations of theoretical development and industrial application have come true or not, and what expectations exist for the near future.

\section{THE PAST AND THE PRESENT}

In the first decade of ecodesign research, from about 1995 to 2005 , there was relatively little focus on the use phase of products, and thus on human and social aspects. The vast majority of common ecodesign strategies focused mainly on material aspects, design for disassembly and recycling [5]. Although many ecodesign researchers patted themselves on the back for having a life-cycle perspective, in reality they did nothing more than contribute with endof-"life-cycle" solutions themselves, focusing on the means to consumption (the product) instead of the practices involved in consumption itself. Research into sustainable consumption has traditionally had relatively little connection to sustainable design and the product level -in terms of research community; these topics have attracted interest from scholars with distinctly different backgrounds and academic perspectives. Strategies related to usage had of course been considered from the early days of ecodesign, such as in tools like the Life Cycle Design Strategy Wheel. But most of these strategies were likewise based on indirect material and end-of-life considerations; life time extension for example appealed to postponing the end-of-life stage, and avoiding the need for material use. Reduction of energy use focused on using technologies requiring less energy consumption. 


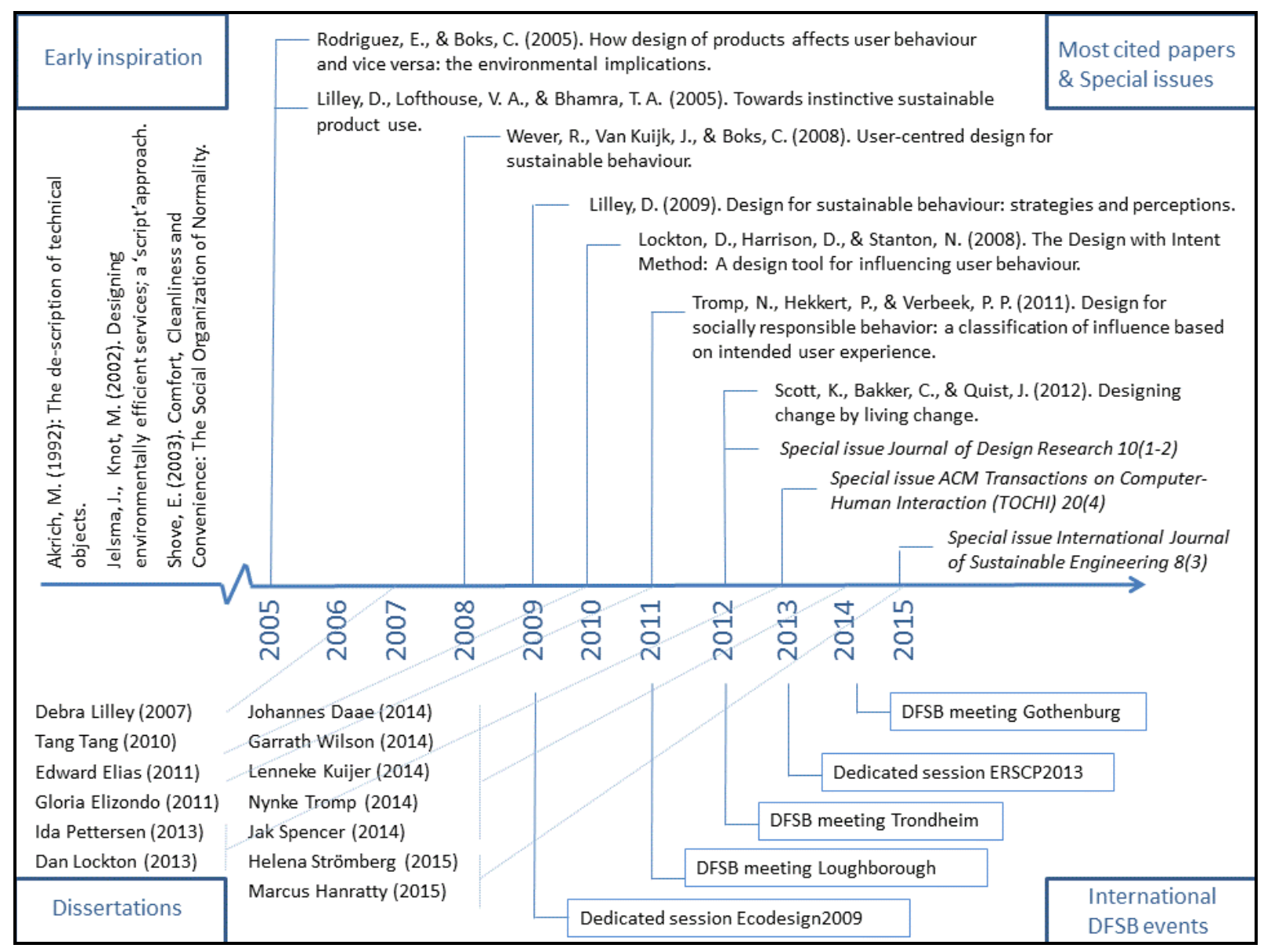

Figure 1: Visualisation of the important milestones in DfSB research [6-18]

As such, academic research in the sustainable product design domain has often been done in the 'design engineering' tradition, usually with limited intent to make truly interdisciplinary connections, as in building or extending scientific theory in, from, with, or for, other scientific domains which may include social sciences, natural sciences, or management sciences.

A lot has changed in the past decade however. Nowadays, many scholars see the potential that design research offers to transdisciplinary perspectives into the development of sustainable solutions. The rapidly emerging field of design for sustainable behaviour, which serves as an example of a transdisciplinary enquiry, which investigates, at various levels, how to influence the sustainability impact of consumers' activities, through studying their behaviors and practices, developed over time and in space. As a result, we have seen an academic network develop, which organizes international workshops and other ways of scholarly cooperation, several dedicated special issues of acknowledged scientific journals [16-18], as well as doctoral dissertations devoted to this theme. Figure 1 visualizes the (arguably) most important academic events related to the development of DfSB as a field of academic interest. It should be noted that the figure represents a very
Northern European perspective, which the authors choose to justify by the fact that the bulk of DfSB literature originates from a limited number of Northern European Universities. Adjacent fields, such as sustainable humancomputer interaction (HCI), critical design and persuasive technology focus on similar research questions but do not affiliate themselves with DfSB and are therefore not within the focus of this overview, nor this paper.

\section{METHOD AND LIMITATIONS}

Just like in 2009, we received 10 completed surveys, though this time fewer surveys were sent out; surveys were only sent to scholars with a completed or almost completed $\mathrm{PhD}$ with a strong relation to Design for Sustainable Behaviour or Sustainable Practices, and to a number of professors that have supervised at least one or more $\mathrm{PhD}$ students within DfSB. Only scholars from Northern Europe were addressed, more specifically those that represent or have represented relevant research groups at Loughborough University (UK), The Royal College of Art (UK), Delft University of Technology (NL), University of Twente (NL), Chalmers University of Technology in Gothenburg, Sweden, and the Norwegian University of Science and Technology in Trondheim, 
Norway. This is obviously a limiting factor, but this was justified by the fact that the majority of scientific publications in the area of DfSB have come from these schools, as mentioned above, and it is this area that we want to investigate in this paper.

The spread among the respondents was $60 \%$ female $/ 40 \%$ male, and the respondents indicated on average 7.3 years of research experience within DfSB.

\section{SURVEY RESULTS BY THEME}

\subsection{Contribution to theoretical fields.}

Respondents were asked their opinion of to what extent 20 different theoretical fields have contributed to the development of DfSB, on a scale from 1 (strongly disagree that it has contributed) to 5 (strongly agree). Figure 2 shows that based on the 2015 survey, three theoretical fields clearly stand out: User-centred design, psychology, and persuasive technology. The figure ranks the fields based on their perceived importance in 2015. It can be observed that some clear shifts in opinion have occurred: Fields such as sociology of consumption, user experience, human factors, practice oriented design and co- and participatory design scored considerably lower in 2015 compared to 2009 . We should mention however that practice theory was not explicitly mentioned as separate field, and respondents may not have associated sociology of consumption with it. Another observation is that now after six years, many more fields received a lower score compared to 2009 (4 fields scoring lower than 2).

A second question addressed which fields respondents expect to deliver important future contributions towards the further development of DfSB should they receive more attention. The results in Figure 3 suggest that expectations about user-centred design and PSS/service design have gone up, whereas behavioural economics and industrial ecology are now regarded as less promising. It is also interesting to note that some the fields mentioned as scoring lower in 2015 than in 2009 for the question on theoretical contributions so far - user experience, codesign and participatory design and sociology of consumption, are still the ones expected to deliver the most important contributions in the future. Obviously, the respondents expect the most contributions from area that are traditionally at the core of design research, and that already have a strong user focus. The integration of disciplines that are more distant to design research, such as those that are closer to the market (marketing, branding, advertising), closer to environmental sciences (industrial ecology) or strategy and management (product innovation management, strategic design) is not considered as pressing (yet). Once sufficient evidence will become available that DfSB-inspired products are effective in their goal to contribute to sustainable behavior, these fields may become more relevant to integrate into DfSB research (see also section 4.3 and Figure 5).

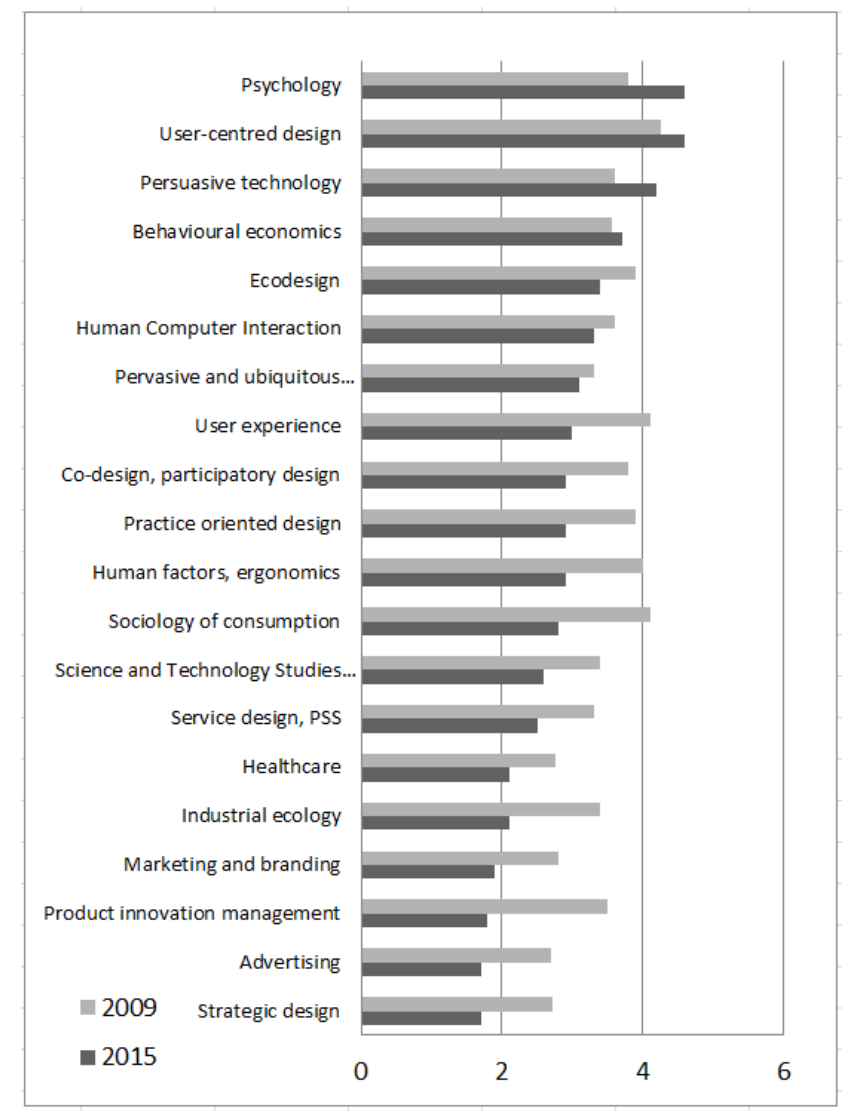

Figure 2: Importance of past contributions of fields

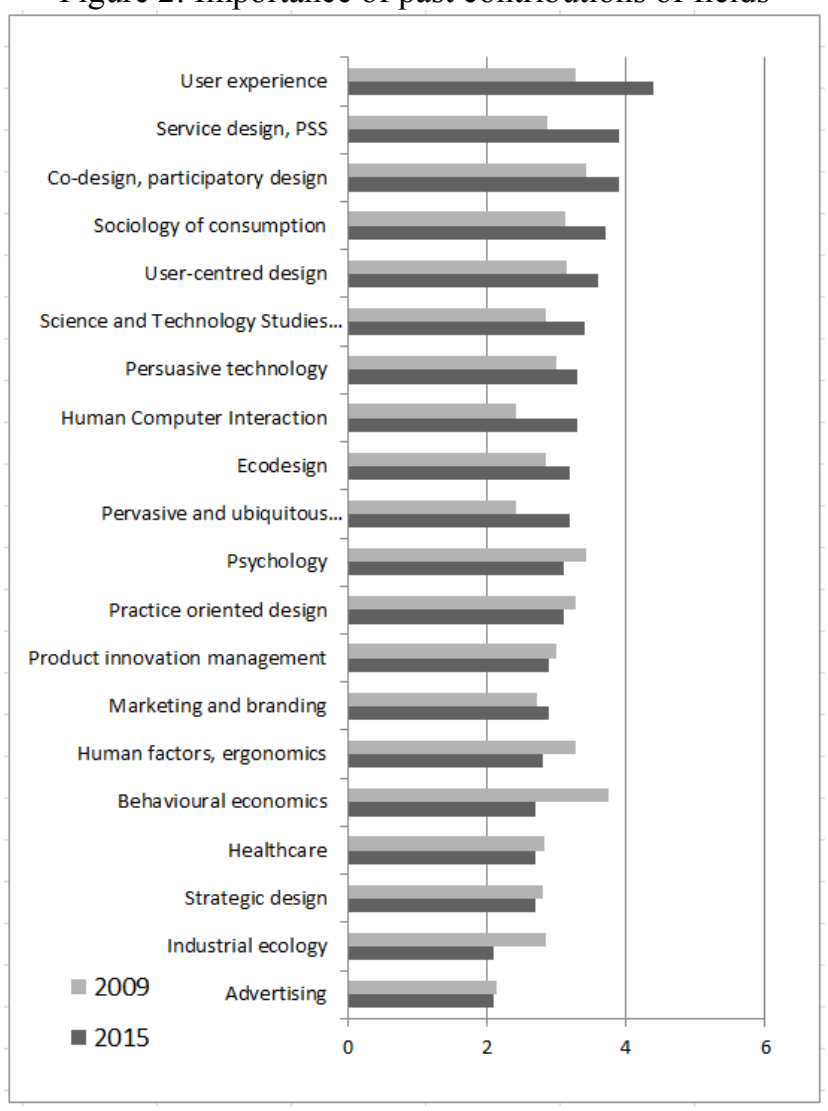

Figure 3: Importance of expected contributions of fields 


\subsection{Research priorities}

Another question addressed perceived research priorities; respondents were asked to rank a number of different topics as unimportant or unappealing theoretical topics (score 1), to very appealing and pressing ones (score 5). Also here some interesting developments can be observed (Figure 4). Evaluation criteria to facilitate the decision making of designers scored highest, with integration into industrial product development practice coming in second place. Perhaps surprisingly, metrics, as in establishing ways of measuring behaviour-related impacts and performance in sustainable product design, scored less compared to 6 years ago, even though it can be argued that these would support the topic of establishing evaluation criteria, the highest scoring topic. However, it is possible, on reflection, to consider that these two topics were not related to each other by respondents.

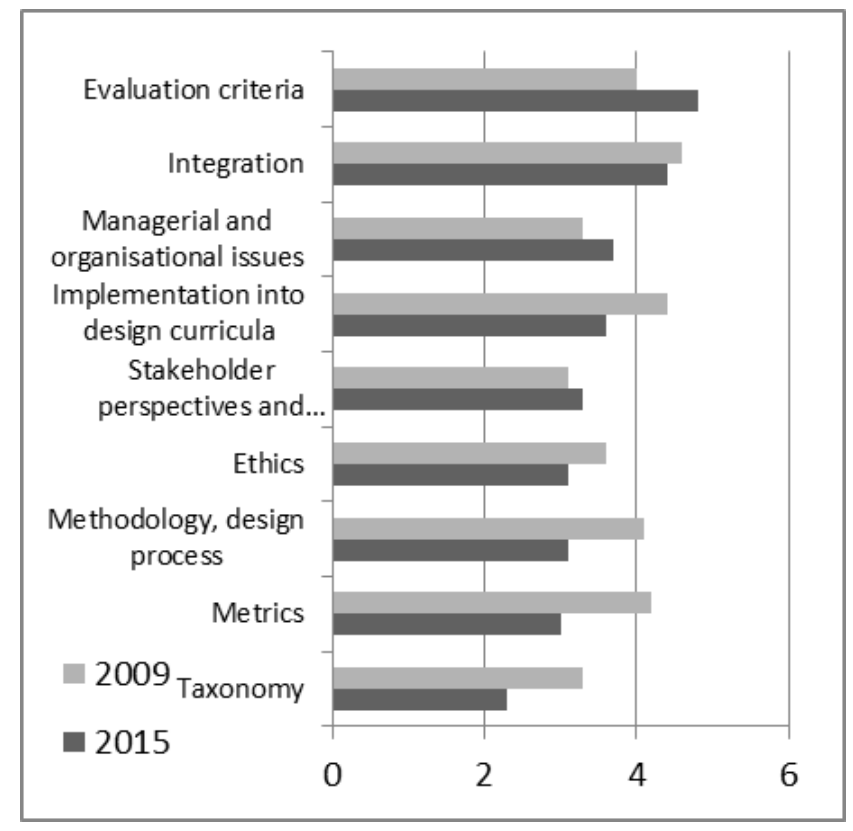

Figure 4: Perception of importance of topics

Figure 4 also suggests that additional theoretical work on DfSB taxonomies (as in classification and categorisation of design strategies) is clearly something that the respondents see as less pressing than before. This may be a response to the observation that a considerable amount of DfSB research has been devoted to this topic over the past years. A new question in the 2015 survey singled out four of these taxonomies, selected from a previous overview listed in Zachrisson and Boks [19], and asked the respondents whether they would 1) commonly use selected taxonomies as a main reference in/for their research, and 2) which one they would prefer to be used as a common reference within DfSB research, both on a scale of 1 to 5 , with $1=$ not used/least preferred, $5=$ usually used/most preferred. Table 1 illustrates that the taxonomy from Zachrisson and Boks [19] is on average preferred over others; 6 out of 10 researchers (from three different research groups) score this taxonomy with a 4 or 5 on the second question.

Respondents replied very similarly compared to 2009 regarding their preferred division of attention for more theoretical research, more applied design research, or more management/organisation oriented research: preferences for more applied design research has somewhat increased (from $46 \%$ to $51 \%$ ) at the cost of more theoretical research (from $32 \%$ to $27 \%$ ) with attention for management/organisation oriented research stable at $22 \%$. This reflects the lack of longitudinal case studies in which strategies have been applied and evaluated versus the aforementioned development of strategies. It also, arguably, points to the need to create an evidence base to prove the success of behaviour changing interventions in order to make a persuasive argument for their use by industrialists who might require firm confirmation of success in practice or otherwise to be convinced that their use could provide them with competitive advantages, given the absence of related regulations, standards and conventions.

\subsection{Integration in business}

Two questions related to the integration of DfSB in industry were included in the survey, just as they were in 2009. Here, respondents were asked about success factors and obstacles for industrial engagement in design for sustainable behaviour, in the context of the 'average consumer electronics multinational'. Though responses were quite similar in both surveys, some interesting shifts could be noted. In 2015, competitive advantage, legislation and innovation were seen as the three main drivers, all scoring higher than in 2009 (Figure 5). Cost savings was no longer seen as being among the main drivers.

Figure 6 represents how respondents assess a number of potential barriers to integration of DfSB in business. The legend for this Figure 6 is provided in Table 2.

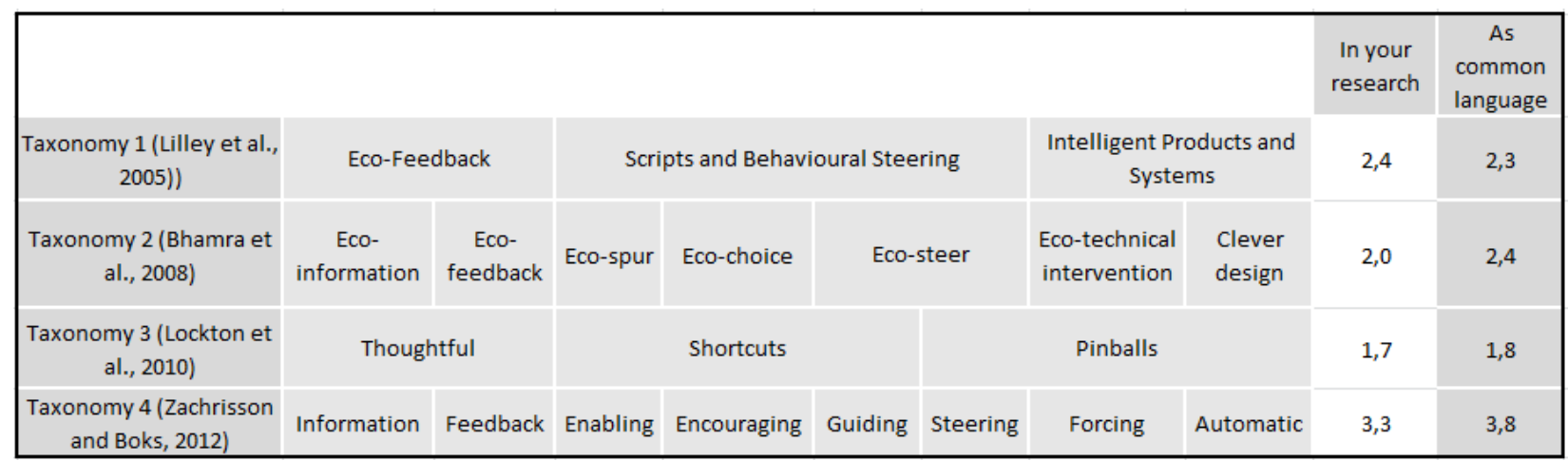

Table 1 : Preference for various taxonomies 


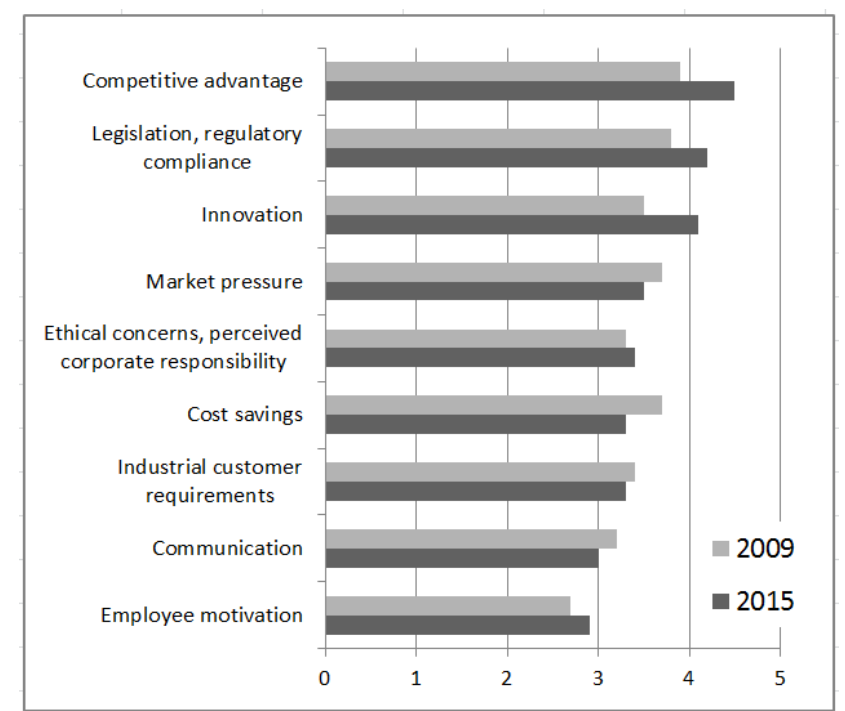

Figure 5: Main drivers for integration in business

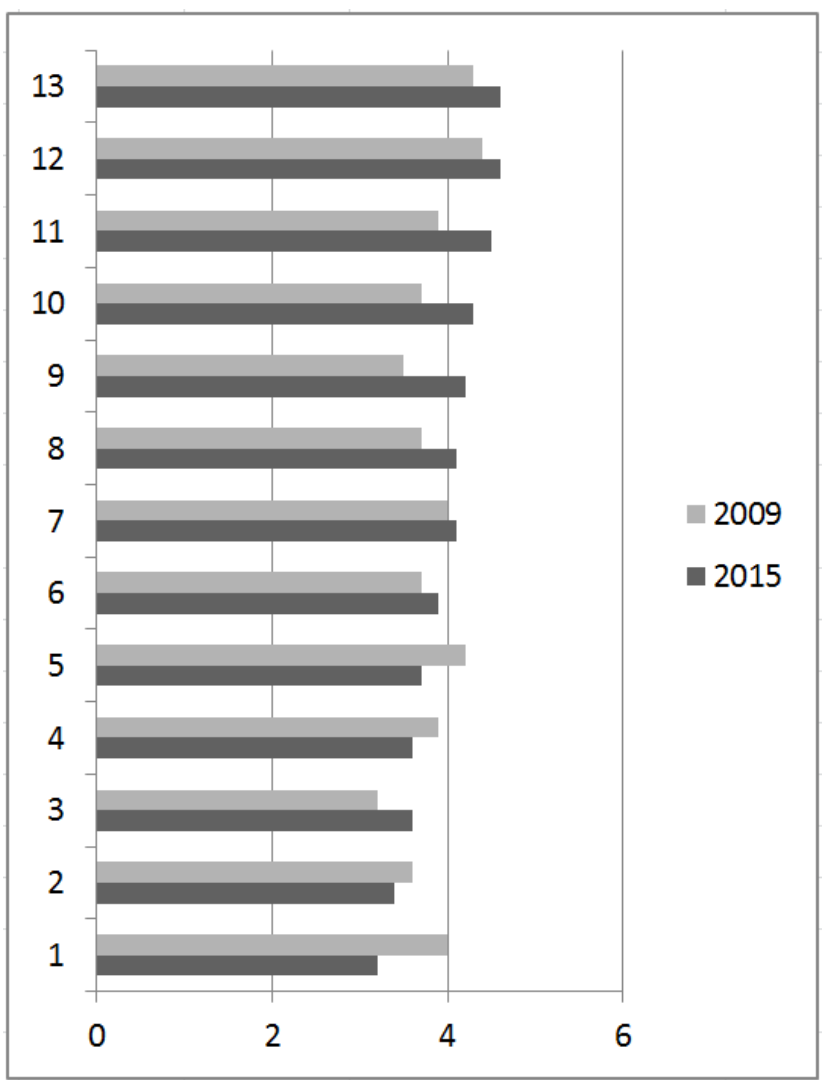

Figure 6: Main obstacles for integration in business

Lack of awareness of 'technology-user interaction'-related sustainability impacts, and time and cost pressures in daily product development were seen as the main barriers in both 2009 and 2015, and even more so in 2015. Lack of consensus on acceptable levels of product influence, and lack of available tools and methods are seen as less as obstacles now compared to 2009, suggesting that research has made advances in these areas.

\begin{tabular}{|l|l|}
\hline 1 & $\begin{array}{l}\text { Lack of awareness of 'technology-user interaction'- } \\
\text { related sustainability impacts }\end{array}$ \\
\hline 2 & $\begin{array}{l}\text { Time and cost pressures in daily product } \\
\text { development }\end{array}$ \\
\hline 3 & Lack of perceived company benefits \\
\hline 4 & $\begin{array}{l}\text { Limited influence of designers on strategic and } \\
\text { managerial issues }\end{array}$ \\
\hline 5 & Lack of perceived company responsibility \\
\hline 6 & Lack of know-how \\
\hline 7 & Lack of perceived market demand \\
\hline 8 & Lack of attention in legislation \\
\hline 9 & Lack of appropriate tools and methods \\
\hline 10 & Increasing product complexity \\
\hline 11 & $\begin{array}{l}\text { Lack of proof as to effectiveness of technological } \\
\text { influence on behaviour }\end{array}$ \\
\hline 12 & Fear of harming customer relationships \\
\hline 13 & $\begin{array}{l}\text { Lack of consensus on acceptable levels of product } \\
\text { influence }\end{array}$ \\
\hline
\end{tabular}

\subsection{Behaviour versus Practice}

Within the research community there is an interesting ongoing debate about the value of practice theory versus more interaction and behaviour oriented research approaches. Behaviour-oriented researchers prefer a behavioural psychology perspective to understand (un)sustainable behaviour, placing individual human beings at centre stage. Social practice theorists draw on sociology and advocate a broad, relational perspective, not studying individuals but practices consisting of material elements, competence and meaning [20] and how they develop in space and time following shared ideas about what is normal. The 2015 survey included a number of statements that respondents were asked to disagree or agree with, using a 5 point Likert scale $(5=$ strongly agree, $1=$ strongly disagree). These statements were loosely formulated and considered to reflect some debates that have been going on, both in literature [15, 21-24], and at conferences. In Table 3 the statements and their replies are presented. Interestingly, almost all statements were met with both strong agreement and strong disagreement among the respondents. The replies suggest that there is support for the statement that both approaches are complimentary, although they are very different, whereas there are less clear shared opinions about whether research should focus on integrating both. Some respondents added interesting opposing thoughts on this issue. There are some that point out fundamental concerns with behaviouroriented approaches, such as (1) a focus on incremental savings that tend to disappear in larger trends, (2) a risk of failing to achieve the intended behaviour change, (3) a strong rhetoric of right and wrong behaviours and (4) a risk of missing opportunities on larger scales of change [23]. Other respondents advocate that these include 


\begin{tabular}{|c|c|c|c|c|}
\hline & $\begin{array}{l}\text { Average } \\
\text { score }\end{array}$ & $\begin{array}{l}\text { Stand. } \\
\text { Dev. }\end{array}$ & $\begin{array}{l}\text { Max. } \\
\text { Score }\end{array}$ & $\begin{array}{l}\text { Min. } \\
\text { Score }\end{array}$ \\
\hline $\begin{array}{l}\text { Behaviour-oriented and practice oriented research are } \\
\qquad \text { very complimentary }\end{array}$ & 4 & 1,154701 & 5 & 2 \\
\hline $\begin{array}{l}\text { Behaviour-oriented and practice oriented research are } \\
\text { inherently different }\end{array}$ & 3,6 & 1,264911 & 5 & 1 \\
\hline $\begin{array}{l}\text { Practice oriented design has limited applicability in } \\
\text { industry contexts }\end{array}$ & 3,5 & 0,849837 & 5 & 2 \\
\hline $\begin{array}{l}\text { It is beneficial for a broader perspective of issues at hand } \\
\text { to integrate both approaches }\end{array}$ & 3,4 & 1,264911 & 5 & 1 \\
\hline $\begin{array}{l}\text { Behaviour-oriented and practice oriented research are } \\
\text { two sides of the same continuum and meet half way }\end{array}$ & 3,3 & 1,418136 & 5 & 1 \\
\hline $\begin{array}{l}\text { It is beneficial for a broader perspective of issues at hand } \\
\text { to keep exploring both approaches separately }\end{array}$ & 2,8 & 1,229273 & 5 & 1 \\
\hline $\begin{array}{l}\text { Behaviour-oriented research leads to suboptimal or even } \\
\text { counter-sustainable design }\end{array}$ & 2,5 & 0,849837 & 4 & 1 \\
\hline
\end{tabular}

Table 3: Scores for statements on behaviour versus practice oriented research

researchers in this field are often (physically) located in a department in which DfSB is only a research niche. In 2009, the respondents were divided about what the ideal environment would be for a DfSB research group, with $45 \%$ preferring a design for sustainability group, and $36 \%$ preferring an interaction design group. Now in 2015, a vast majority of $90 \%$ sees broader design for sustainability research as a preferred research

contrived arguments, and that positioning practice and behaviour oriented approaches against each other is counterproductive; that designers are inherently magpies, picking up whatever little bits of knowledge and theory might help to gain meaning and develop successful solutions; and that both theoretical viewpoints can be useful to achieve this, and each can inform the other. Based on the annotations made by the majority of the respondents, who, granted, mostly affiliate themselves with behaviour rather than practice oriented research, it is safe to say that most of them interpret and adapt these and other theories in a broader holistic sense than, perhaps, the disciplines where they originated. If the end goal of DfSB is to reduce the social and environmental impact of activities that individuals engage in through interaction with the world around them, it is implicit that the designed artefacts and systems are acceptable, usable and even desirable to users, and therefore commercially interesting for firms to offer. One respondent wrote that a practice level intervention may have a large potential for resource saving, but opportunities for 'radical' change may not be desirable to users for any number of reasons (e.g. comfort, financial, logistical, perceptual, etc). For that matter, the exact same holds for a behavioural or technological intervention. DfSB, just like any other design discipline, is not beholden to fully adopt any other academic field's knowledge paradigm, particularly in a subject as complex as the fields of human behaviour. These theories are abstractions, simplified ways of viewing an incomplete picture. What is relevant is their usefulness, if any, to the designer and/or design researcher; any theory is only as useful as it proves itself in practice. This debate is likely to be on-going, and indeed should form the basis of further academic discussion.

\subsection{Location and position of DfSB}

Design for Sustainable Behaviour is obviously an inter- or transdisciplinary research and application field. Although it provides an opportunity for different groups with different backgrounds to work together, reality is that environment. Many respondents were relatively outspoken about the fact that the context in which research is to be performed needs to be design, and needs to be sustainability, in order for DfSB to develop in the right direction, provided that the field can interact with a great variety of research environments. It was stated that even though embedding the topic in an interaction design environment could provide a great deal of opportunities, especially when framed as sustainable HCI, its current position which is mostly outside interaction design and HCI has provided a unique position to develop, and has led to a distinct canon of knowledge and lens on technologically mediated behavior. One respondent stated that as a field, and compared to interaction design in many aspects DfSB is more comfortable with the concepts and potential for Internet of Things and physical computing, as it has developed a rich understanding of the agency designed products can exert on our lives. To an extent, being positioned in the area of sustainability also allowed space for the ethical concerns to be explored at a remove from commercial pressures. Similarly, a development outside sociology and psychology has created a very explanatory and descriptive focus which is often inherent to design research.

\section{SOME THOUGHTS ABOUT THE FUTURE}

At the end of the survey, some statements were given that probed into the respondents' expectation on how the field will further develop. Interestingly, the analysis of the responses suggests a lack of consensus on a number of issues. There was an equal number of respondents that agreed, disagreed, or were unsure about 1) whether the number of PhD students that will work on DfSB themes at Northern European universities will double in the next five years, 2) about whether DfSB research will turn out to have been an research niche, becoming less visible in five years, and 3) whether academic DfSB research so far has contributed to commercial DfSB solutions that can be seen 
on the market today. There were, however, few that expect the launch of a dedicated scientific journal devoted to DfSB.

But there is strong agreement (save one exception) among the respondents, that Design for Sustainable Behaviour and/or Practices will be a significant element of their jobs in five years from now. The senior respondents with tenured positions in academia expect to continue there, whereas most $\mathrm{PhD}$ students were unsure whether this would be in academia or elsewhere. This suggests that DfSB is an exciting and inspiring field to work with that is expected to provide challenging research opportunities also within the next years. These could include a broader application of current DfSB approaches. As is reflected by both the 2009 and 2015 survey, so far the (implicit?) background context or goal for much of the DfSB research has been the eventual application of DfSB approaches in industry, resulting in design interventions, on both smaller and bigger scales (but perhaps mostly smaller scale as in products - as illustrated by most case studies available). In the future, DfSB could focus on the role of other actors relevant to design and use (energy utilities, the public sector, NGOs, etc.) and the development of interventions involving multiple actors. Another approach could be to take DfSB approaches with firms, or other organisations, themselves as actors, as in how these could be informed or forced, or most interestingly, seduced to integrate sustainability into their activities, or study the practices of designers and others, to identify opportunities for influencing the direction in which they develop. But, as the results from the questions about the importance of various theoretical fields discussed in section 4.1 suggest, this is not high on the agenda. Perhaps a re-revisitation of the survey in, say 2021, will show a different picture.

\section{ACKNOWLEDGEMENTS}

The authors would very much like to thank our colleagues that kindly responded to the survey. In addition we would like to express our appreciation for being part of a very interesting research community.

\section{REFERENCES}

[1] Daae, J., Boks, C. (2015) Opportunities and challenges for addressing variations in the use phase with LCA and Design for Sustainable Behaviour, International Journal of Sustainable Engineering, 8:3, $148-162$

[2] Lilley, D., \& Wilson, G. T. (2013). Integrating ethics into design for sustainable behaviour. Journal of Design Research, 11(3), 278-299.

[3] Pettersen, I.N., Boks, C. (2008). The ethics in balancing control and freedom when engineering solutions for sustainable behaviour. International Journal of Sustainable Engineering, 1(4), 287-297.

[4] Pettersen, I.N., Boks, C., The future of design for sustainable behaviour. Ecodesign 2009: Sixth
International Symposium on Environmentally Conscious Design and Inverse Manufacturing, December 7-9. 2009, Sapporo, Japan

[5] Boks, C., \& McAloone, T. C. (2009). Transitions in Sustainable Product Design Research. International Journal of Product Development, 9(4), 429-449.

[6] Akrich, M. (1992): The de-scription of technical objects. In W. Bijker and J. Law (Eds.) Shaping Technology, Building Society: Studies in Sociotechnical Change. Cambridge, Mass, MIT Press: 205-224.

[7] Jelsma, J., Knot, M. (2002): Designing environmentally efficient services; a 'script' approach. The Journal of Sustainable Product Design, 2, 119-130

[8] Shove, E. (2003). Comfort, cleanliness and convenience: The social organization of normality (Vol. 810). Oxford: Berg

[9] Rodriguez, E., \& Boks, C. (2005). How design of products affects user behaviour and vice versa: the environmental implications. In Environmentally Conscious Design and Inverse Manufacturing, 2005. Eco Design 2005. Fourth International Symposium on (pp. 54-61). IEEE.

[10] Lilley, D., Lofthouse, V. A., \& Bhamra, T. A. (2005). Towards instinctive sustainable product use.

[11] Wever, R., Van Kuijk, J., \& Boks, C. (2008). User-centred design for sustainable behaviour. International journal of sustainable engineering, 1(1), 9-20.

[12] Lilley, D. (2009). Design for sustainable behaviour: strategies and perceptions.Design Studies, 30(6), 704-720

[13] Lockton, D., Harrison, D., \& Stanton, N. A. (2010). The Design with Intent Method: A design tool for influencing user behaviour. Applied ergonomics, 41(3), 382-392.

[14] Tromp, N., Hekkert, P., \& Verbeek, P. P. (2011). Design for socially responsible behavior: a classification of influence based on intended user experience. Design Issues, 27(3), 3-19.

[15] Scott, K., Bakker, C., \& Quist, J. (2012). Designing change by living change. Design Studies, 33(3), 279297.

[16] Wever, R. (2012). Editorial: Design research for sustainable behaviour. Journal of Design Research, $10(1-2), 2012$

[17] Pierce, J., Strengers, Y., Sengers, P., and Bødker, S. 2013. Introduction to the special issue on practiceoriented approaches to sustainable HCI. ACM Trans. Comput.-Hum. Interact. 20, 4, Article 20 (September 2013), 8 pages.

[18] Bhamra, T. and Lilley, D. Editorial IJSE special issue: Design for Sustainable Behaviour. 
International Journal of Sustainable Engineering. Volume 8, Issue 3, 2015

[19] Zachrisson, J., \& Boks, C. (2012). Exploring behavioural psychology to support design for sustainable behaviour research. Journal of Design Research 14,10(1-2), 50-66.

[20] Shove, E.; Pantzar, M.; Watson, M. (2012): The dynamics of social practice: everyday life and how it changes, SAGE Publications Ltd, London

[21] Pettersen, I. N., Boks, C., \& Tukker, A. (2013). Framing the role of design in transformation of consumption practices: beyond the designer-product- user triad. International Journal of Technology Management, 63(1-2), 70-103.

[22] Kuijer, S. C. (2014). Implications of social practice theory for sustainable design (Doctoral dissertation, TU Delft, Delft University of Technology)

[23] Kuijer, L., Bakker, C. (2015) Of chalk and cheese: behaviour change and practice theory in sustainable design, International Journal of Sustainable Engineering, 8:3, 219-230 